\title{
KEPEMIMPINAN ENTREPRENEURSHIP KEPALA SEKOLAH DALAM MENINGKATKAN KEMANDIRIAN PEMBIAYAAN SEKOLAH
}

\author{
Nur Komariah \\ Dosen Manajemen Pendidikan Islam Universitas Islam Indragiri \\ e-mail: nurkomariah1@gmail.com
}

\begin{abstract}
Abstrak
Entrepreneurship merupakan salah satu diantara lima kompetensi yang harus dimiliki kepala sekolah. Kepemimpinan entrepreneurship kepala sekolah sangat diperlukan di era globalisasi. Kepala sekolah dituntut untuk mampu memberikan inovasi dan kreativitasnya terlebih dalam hal pembiayaan pendidikan. Kepemimpinan entrepreneurshipdalam meningkatkan kemandirian pembiayaan berarti kepala sekolah mampu berfikir inovatif dan kreatif dalam penggalian sumber-sumber pembiayaan pendidikan, tidak bergantung dengan pihak lain, mampu memberikan kemandirian pembiayaan sehingga tetap survive dan mampu bersaing baik tingkat nasional maupun internasional.
\end{abstract}

Keyword: Kepemimpinan. Entrepreneurship. Pembiayaan.

\section{A. Pendahuluan}

Kepemimpinan dalam konsep Islam sering disebutkan dengan menggunakan istilah imamah (imam) ${ }^{1}$, khalifah (mengganti) ${ }^{2}$, atau

${ }^{1}$ Ahmad Warson Munawir, Al-Munawwir, (Yogyakarta: Pustaka Progressif, 1997), h. 48

${ }^{2}$ Ibid., h. 361 . 
Vol. V, No. 1, April 2017

imaroh (kekuasaan). ${ }^{3}$ Dalam hal ini kepemimpinan dihubungkan dengan hidayah atau pemberian petunjuk jalan yang benar pada semua orang sehingga mendapatkan keselamatan dan kebahagiaan dunia dan akhirat. Seorang pemimpin akan senantiasa menciptakan kedamaian pada lingkungan yang dipimpinnya, memberikan kesejukan serta kedamaian pada lingkungan yang dipimpinnya. hal ini sesuai dengan Misi Allahmenciptakan Manusia yakni untuk memakmurkan bumi bukan membuat kerusakan bumi sebagaimana di khawatirkan oleh para malaikat Allah hal ini sebagaimana Firman Allah sebagai berikut:

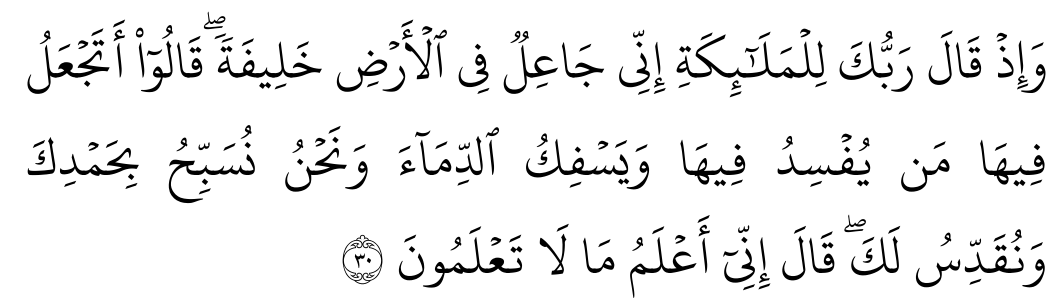

Ingatlah ketika Tuhanmu berfirman kepada Para Malaikat: "Sesungguhnya aku hendak menjadikan seorang khalifah di muka bumi." mereka berkata: "Mengapa Engkau hendak menjadikan (khalifah) di bumi itu orang yang akan membuat kerusakan padanya dan menumpahkan darah, Padahal Kami Senantiasa bertasbih dengan memuji Engkau dan mensucikan Engkau?" Tuhan berfirman: "Sesungguhnya aku mengetahui apa yang tidak kamu ketahui." (Q.S: Al-Baqoroh.30) ${ }^{4}$

Berdasarkan ayat di atas, dapat difahami bahwa tujuan penciptaan manusia di muka bumi ini adalah untuk menjadi pemimpin (khalifah). Seorang pemipin sebagaimana digambarkan pada ayat di atas adalah seorang yang tidak membuat kerusakan serta kejahatan namun seorang

\section{${ }^{3}$ Ibid., h.38}

${ }^{4}$ Anonim, Al-qur'an Terjemah \& Penjelasan Ayat Tentang Wanita,(Solo: Tiga Serangkai, 2013), h. 6 
pemimpin adalah seseorang yang mampu memakmurkan bumi, menebar kedamaian dan keadilan.Hal ini tentu saja adalah seorang yang mempunyai kompetensi terkait lingkungan yang akan dipimpinnnya. hal ini sebagaimana diungkapkan oleh Jejen Musfah bahwa pemimpin adalah seseorang yang mempunyai kemampuan mempengaruhi perilaku orang lain dengan menggunakan kekuasaan. ${ }^{5}$ Kekuasaan adalah kemampuan untuk mengarahkan dan mempengaruhi bawahan sehubungan dengan tugas-tugas yang harus dilaksanakannya. ${ }^{\mathbf{6}}$

Dalam sebuah lingkungan pendidikan dasar dan menengah seorang pemimpin atau disebut juga dengan kepala sekolah adalah seorang tenaga fungsional guru yang diberikan tugas tambahan untuk memimpin suatu sekolah dimana diselenggarakan proses belajar mengajar atau tempat dimana diselenggarakan proses belajar mengajar atau tempat dimana terjadi interaksi antara guru yang memberi pelajaran dan murid yang menerima pelajaran. ${ }^{7}$

Dari pengertian di atas dapat difahami bahwa kepala sekolah memiliki peran lebih dibandingkan dengan guru. Plunkett dan Attner dalam Jujun Musfah menyebutkan, peran kepala sekolah yaitu sebagai pendidik, penasihat, penilai dan juru bicara. Untuk dapat menjalankan perannya dengan penuh tanggung jawab, seorang kepala harus memiliki sejumlah kompetensi. ${ }^{8}$ Charles dalam Imam Musbikin

5 Jejen Musfah, Manajemen Pendidikan: Teori, Kebijakan, dan Praktik, (Jakarta: Prenada Media Group, 2015), h. 300.

${ }^{6}$ Ibid.

${ }^{7}$ Imam Musbikin, Menjadi Kepala Sekolah yang Hebat, (Pekanbaru: Zanafa, 2013), h. 8.

${ }^{8}$ Jejen Musfah, Manajemen Pendidikan: Teori, Kebijakan, dan Praktis... h. 302. 
Vol. V, No. 1, April 2017

menyebutkan: "competency as rational performance which satisfactorily meets the objective for a desired condition". 9

Dalam Peraturan Menteri Pendidikan Nasional Nomor 13 Tahun 2007 tentang Standar Kepala Sekolah/Madrasah dikemukakan bahwa setiap sekolah/madrasah harus memiliki 5 (lima) kompetensi dasar; yaitu kompetensi kepribadian, manajerial, supervisi, sosial, dan kewirausahaan (entrepreneurship).

Dalam tulisan ini penulis memfokuskan pembahasan pada kompetensi kewirausahaan(Entrepreneurship) yakni bagaimana mengembangkan kompetensi entrepreneurshipkepala sekolah guna meningkatkan kemandirian pembiayaan pendidikan.

\section{B. Pengertian Entrepreneur dan entrepreneurship}

Entrepreneur berasal dari bahasa perancis entreprende yang berarti "to undertake " between-taker, go-between (perantara). Dalam bahasa Indonesia Istilah entrepreneur sering juga disebut dengan wiraswasta atau wirausahawan, dan istilah entrepreneurship diartikan sebagai kewirausahaan atau kewiraswastaan yang artinya keberanian, kesungguhan, dan keseriusan dalam memecahkan persoalan hidup yang dihadapinya. Menurut Kasmir wirausahawan (entrepreneur) adalah orang yang berani mengambil resiko untuk membuka sebuah usaha dalam berbagai kesempatan. ${ }^{10}$

Entrepreneur dalam kontek pendidikan berarti bahwa kepala sekolah mampu menggunakan kekuasaannya sebagai alat untuk

\footnotetext{
${ }^{9}$ Imam Musbikin, Menjadi Kepala Sekolah yang Hebat... h. 51.

${ }^{10}$ Kasmir, Kewirausahaan, (Jakarta: RajaGrafindo Persada, 2014), h. 19
} 
mengeluarkan kebijakan yang mampu memandirikan sekolah yang dipimpinnnya serta bebas dari keterikatan dengan lembaga lain. Seorang entrepreneur dalam konteks pendidikan akan berupaya bagaimana mewujudkan sekolah yang mandiri tidak bergantung dengan lembaga lain, sekolah yang mampu melahirkan lulusan-lulusan yang unggul serta mampu mandiri tidak menjadi beban masyarakat.

Mulyasa menjelaskan jiwa entrepreneurship bisa dimiliki oleh setiap peserta didik manakala lingkungan sekolah mampu membiasakan peserta didik untuk berfikir kreatif dan inovatif sebagai dasar, kiat dan kekuatan untuk memanfaatkan peluang menuju sukses. ${ }^{11}$

Menurut Hisrich et al dalam Uhar suharsaputra entrepreneurship adalah proses, dimana diciptakan sesuatu yang berbeda yang bernilai, dengan jalan mengorbankan waktu dan upaya yang diperlukan, dimana orang menanggung resiko finansial, psikologis, serta sosial, dan orang yang bersangkutan menerima hasil-hasil berupa imbalan moneter, dan kepuasan pribadi sebagai dampak kegiatan itu" 12

Berdasarkan pengertian di atas, maka diketahui unsur-unsur yang dapat membentuk kewirausahaan adalah 1) sikap mental, 2) kepemimpinan, 3) manajemen, dan 4) keterampilan. Kepala sekolah yang memiliki jiwa entrepreneur memiliki tujuan-tujuan yang diintegrasikan dalam visi dan misi, tujuan, dan rencana strategis sekolah secara realistik, sesuai dengan kemampuan, kondisi dan mampu

${ }^{11}$ Mulyasa, Manajemen \& Kepemimpinan Kepala Sekolah, (Jakarta: Bumi Aksara, 2015), h. 189

12 Uhar Suharsaputra, Kepemimpinan Inovasi Pendidikan:Mengembangkan Spirit Entrepreneurship Menuju Learnig School, (Bandung: Refika Aditama, 2016), h.79 
Vol. V, No. 1, April 2017

memanfaatkan sumber daya yang ada di sekolah guna dapat mendukung tercapainya visi sekolah.

\section{Kepemimpinan Entrepreneruship Kepala Sekolah}

Kepemimpinan dalam sebuah organisasi merupakan salah satu faktor penting dalam menentukan keberhasilan sebuah organisasi. salah satu faktor penting dari kepemimpinan selain karakter yang dimiliki seorang pemimpin adalah skiils(kompetensi) yang dimiliki seorang pimpinan. Kompetensi dan karakter bagaikan dua sisi mata uang yang tidak bisa dipisahkan satu sama lain. Seorang yang memiliki karakter yang demokrasi namun tidak memiliki kompetensi juga kurang dapat mencapai tujuan organisasi. namun sebaliknya pemimpin yang memiliki sejumlah kompetensi namun tidak didukung karakter yang baik juga tidak akan efektif.

George R. Terry dalam Herabudin menyebutkan bahwa Kepemimpinan adalah aktitivitas mempengaruhi orang lain untuk secara sukarela mau berjuang mencapai tujuan-tujuan kelompok. ${ }^{13}$ Pengertian di atasmengandung dua aspek penting, yaitu:

1. Adanya usaha dari pemimpin untuk mempengaruhi orang lain.

2. Adanya tujuan-tujuan kelompok yang akan dicapai.

Sementara itu menurut Muhaimin et al Kepemimpinan adalah proses memberikan pengaruh secara sosial kepada orang lain sehingga orang tersebut mau menjalankan proses sebagaimana yang diinginkan

13 Herabudin, Administrasi dan Supervisi Pendidikan, (Bandung: Pustaka Setia, 2009), h. 186 
oleh pemimpin guna mencapai tujuan organisasi. ${ }^{14}$ Selanjutnya Miftah Thoha dalam kesimpulannya menyebutkan bahwa kepemimpinan adalah "aktivitas untuk mempengaruhi perilaku orang lain agar mereka mau diarahkan untuk mencapai tujuan tertentu." 15

Adapun kepemimpinan entrepreneur Hitts, Ireland, dan Hoskisson dalam Uhar Suharsaputramenyebutkan bahwa: "Entrepreneurial Leadership... as the entrepreneur's ability to anticipate, envision, maintain flexibility, think strategically, and work whith others to changes that will create a viable future for the organization"16

Dari beberapa pengertian di atas, dapat disimpulkan bahwa pengertian kepemimpinan entrepreneurshipkepala sekolah adalah kepemimpinan seorang kepala sekolah yang mempunyai kemampuan mengantisipasi perubahan, yang mampu menunjukkan dengan jelas visi yang ingin diwujudkan, berfikir strategis, fleksibel, yang mampu mengantisipasi perubahan, serta berorientasi pada masa depan.

Dari pengertian di atas, Dave Lavinsky dalam Uhar Suharsaputra menyebutkan karakteristik kepemimpinan entrepreneur sebagai berikut:

1. "build trust and confidence among employess; membangun kepercayaan dan keyakinan diantara para pegawai.

${ }^{14}$ Muhaimin et al, Manajemen Pendidikan: Aplikasinya dalam Penyusunan Rencana Pengembangan Sekolah/Madrasah, (Jakarta: Kencana Prenada Media Group, 2011), h. 29

${ }^{15}$ Miftah Thoha, Kepemimpinan dalam Manajemen, (Jakarta: Rajawali Pers, 2012), h. 121.

${ }^{16}$ Uhar Suharsaputra, Kepemimpinan Inovasi Pendidikan: Mengembangkan Spirit Entrepreneurship Menuju Learnig School... h. 91 
Vol. V, No. 1, April 2017

2. Communicate effetively with them; berkomunikasi secara efektif dengan pegawai.

3. Seeking self improvement: A great leader always seeks to become even bette; memperbaiki diri: pemimpin besar selalu berupaya menjadi lebih baik.

4. Possessing technical skills: while the leader may not need to have the greatest technical skills in their organization, they need to be savvy enough to lead team; memiliki keterampilan teknis. Mereka memerlukan kepandaian untuk memimpin tim.

5. Accepting responsibility for actions: leaders and companies always make mistakes. Great leaders don't place blame on others; bertanggung jawab atas tindakan dan tidak menyalahkan orang lain.

6. Making decisions: good leaders must make good and timely decisions; membuat keputusan dengan vaik da tepat waktu.

7. Being a role model: A leader must set an example to employess and guide them to excel; menjadi model keteladanan bagi para pegawai guna membimbing mereka untuk mencapai hal yang hebat. ${ }^{17}$

${ }^{17}$ Ibid., h. 99-100. 
Nur Komariah

\section{Pembiayaan pendidikan dan Sumber-Sumber Pembiayan Pendidikan}

Pembiayaan pendidikan merupakan aktivitas yang berhubungan dengan pemerolehan dana (pendapatan) yang diterima sekolah, bagaimana dana dibelanjakan, siapa yang membelanjakan serta bagaimana dana dipertanggungjawabkan. ${ }^{18}$

Pada umumnya sumber pembiayaan pendidikan di sekolahsekolah berasal dari dana rutin, yaitu gaji, serta biaya operasional sekolah dan perawatan fasilitas (OPF), serta dana yang berasal dari masyarakat, baik itu dana yang berasal dari orang tua siswa, masyarakat luas maupun dari dunia usaha. Hal ini sebagaimana diungkapkan oleh Fattah dalam Akdon et al menyebutkan bahwa sumber-sumber keuangan sekolah dapat bersumber dari orang tua, pemerintah pusat, pemerintah daerah, swasta, dunia usaha, dan alumni. ${ }^{19}$ Sementara itu menurut Sulistiyorini sumber pembiayaan sekolah Islam dapat dikelompokkan atas tiga sumber, yaitu:

1. Pemerintah, baik pemerintah pusat, daerah, maupun keduaduanya yang bersifat umum atau khusus dan diperuntukkan bagikepentingan pendidikan.

2. Orang tua atau peserta didik.

3. Masyarakat, baik mengikat maupun tidak mengikat. ${ }^{20}$

${ }^{18}$ Akdon et al, Manajemen Pembiayaan Pendidikan, (Bandung: Rosdakarya, 2015), h. 23.

${ }^{19}$ Ibid., h. 87

${ }^{20}$ Sulistiyorini, Manajemen Pendidikan Islam: Konsep, strategi, dan Aplikasi, (Yogyakarta: Teras, 2009), h. 130 
Vol. V, No. 1, April 2017

Sementara itu, menurut Mujamil untuk menggali dan mengumpulkan sumber pembiayaan pendidikan dapat ditempuh melalui cara-cara berikut di bawah ini:

1. Mengajukan proposal bantuan finansial ke Departemen Agama maupun Departemen Pendidikan Nasional.

2. Mengajukan proposal bantuan finansial ke pemerintah daerah.

3. Mengedarkan surat permohonan bantuan kepada wali siswa.

4. Mengundang alumni yang sukses untuk dimintai bantuan.

5. Mengajukan proposal bantuan finansial kepada para pengusaha.

6. Mengadakan kegiatan-kegiatan yang dapat mendatangkan keuntungan uang.

7. Memberdayakan waqaf, hibah, atau infaq.

8. Memberdayakan solidaritas anggota organisasi keagamaan yang menaungi lembaga pendidikan Islam untuk membantu pencarian dana. ${ }^{21}$

Pembiayan dalam pendidikan menduduki peran yang sangat penting guna terciptanya proses pembelajaran yang aktif, kreatif, efektif dan menyenangkan. Dengan pembiayaan yang mendukung guru akan mudah mendapatkan sarana dan prasarana pembelajaran guna dapat memudahkan bagi siswa memahami setiap materi yang akan disampaikan oleh guru. Mulai dari ketersediaan bahan ajar dan belajar, labor, halaman serta taman yang bersih dan sejuk, lingkungan yang sehat serta fasilitas-fasilitas pendukung lainnnya.

${ }^{21}$ Mujamil Qomar, Manajemen Pendidikan Islam: Strategi Baru Pengelolaan Lembaga Pendidikan Islam, (Jakarta: Erlangga, 2008), h. 150-151 
Untuk mencukupi semua kebutuhan sekolah tentu tidak semudah membuat proposal yang kemudian langsung disetujui dan cair, oleh karena itu kepala sekolah entrepreneurakan selalu berfikir inovatif serta tidak mudah bergantung dengan lembaga laindan akan terus berfikir untuk dapat memberikan inovasi sekaligus solusi berkenaan dengan masalah pembiayaan guna dapat mendukung tercapainya mutu pendidikan sehingga dapat bersaing baik tingkat nasional maupun internasional.

\section{E. Bentuk-Bentuk Usaha Sekolah}

Seiring perkembangan zaman yang menuntut akan adanya perkembangan dari berbagai sektor, lembaga pendidikan dituntut untuk mampu memberikan perannya dalam bentuk menghasilkan lulusalulusan yang mandiri, mampu memberikan solusi bagi negara bukan malah justru menjadi beban bagi negara. Oleh karena itu, tidak mengherankan jika saat ini banyak sekolah-sekolah swasta yang memanfaatkan otonomi untuk dapat berinovasi memajukan sekolahsekolah yang dipimpinnya. Banyak sekolah-sekolah yang saat ini memiliki sejumlah badan usaha atas nama milik sekolah atau yayasan sehingga mampu mandiri secara pembiayaan. Oleh karena itu tidak mengherankan jika saat ini banyak sekolah-sekolah swasta yang secara finansial lebih berdaya dibandingkan dengan sekolah-sekolah yang berstatus negeri. Bahkan tidak jarang sekolah yang berstatus swasta lebih unggul dibandingkan sekolah negeri.

Salah satunya upaya kepala sekolah entrepreneurship untuk kemandirian pembiayaan adalah dengan memberdayakan wakaf, infaq 
Vol. V, No. 1, April 2017

dan sedekah. Salah satunya dengan memanfaatkan dana wakaf dengan pengelolaan dana wakaf yang baik, dana wakaf akan tumbuh dan berkembang sehingga tidak mustahil mampu memberikan kesejahteraan masyarakat sekolah dan masyarakat sekitar sekolah. Salah satu bentuk pemberdayaan dana tersebut adalah dengan memanfaatkannya sebagai modal penumbuhan udan pengembangan usaha.

Diantara bentuk-bentuk usaha yang dapat dikembangkan bagi pemula sesuai dengan minat dan bakat yakni:1). sektor kecantikan, 2). sektor keterampilan, 3). sektor konsultan, 4). sektor industri, 5). sektor tambang, 6). sektor kelautan, 7). sektor perikanan, 8). sektor agribisnis, 9). sektor perdagangan, 10). sektor pendidikan, 11). sektor percetakan, 12). sektor seni, 13). sektor kesehatan, 14). sektor pariwisata dan sektor lainnya. ${ }^{22}$

Untuk menentukan jenis usaha yang akan dijalankan disekolah, kepala sekolah entrepreneurshipharus mempertimbangkan terlebih dahulu jenis usaha apa yang akan dibuka dengan mempertibangkan minat dan bakat, ketersediaan modal dan waktu, keuntungan (laba) serta pengalaman. ${ }^{23}$

\section{F. Strategi mengembangkan Entrepreneurship di Sekolah}

Entrepreneur dalam dunia pendidikan berarti bagaimana memadukan kepribadian, peluang, keuangan, dan sumber daya yang terdapat di lingkungan sekolah untuk mengambil keuntungan.

\footnotetext{
${ }^{22}$ Kasmir, Kewirausahaan... h. 44-47

${ }^{23}$ Ibid., h. 44-45
} 
Kepribadian tersebut mencakup pengetahuan, keterampilan, sikap, dan perilaku. ${ }^{24}$ Steinhoff dalam Mulyasa mengidentifikasikan karakteristik kepribadian kepala sekolah entrepreneur sebagai berikut:

1. Percaya diri (Self confidence)yang tinggi, pekerja keras, cerdas, mandiri, dan berani menanggung resiko dari keputusan yang diambil.

2. Memiliki kreativitas diri (self creativity) tinggi, kemauan dan kemampuan mencari alternatif untuk merealisasikan berbagai kegiatan melalui kewirausahaan.

3. Memiliki pikiran positif (positive thinking)dalam menghadapi suatu masalah atau kejadian senantiasa melihat aspek positifnya. Dengan begitu kepala sekola entrepreneur akan senantiasa melihat peluang dan memanfaatkannya untuk mendukung kegiatan yang dilakukan.

4. Memiliki orientasi pada hasil (output oriented).

5. Memiliki keberanian untuk mengambil resiko.

6. Memiliki jiwa pemimpin.

7. Berfikir orisinal, selalu punya gagasan baru, baik untuk mendapatkan peluangmaupun mengatasi masalah secara kreatif dan inovatif.

8. Memiliki orientasi ke depan, menggunakan masa lalu sebagai pembelajaran untuk meningkatkan prestasi kerjanya.

${ }^{24}$ Mulyasa, Manajemen \& Kepemimpinan Kepala Sekolah, ( Jakarta: Bumi Aksara, 2015), h. 192. 
Vol. V, No. 1, April 2017

9. Suka tantangan, dan menemukan diri dengan merealisasikan ide-idenya. ${ }^{25}$

Kepala sekolah entrepreneurship dalam pelaksanaannya harus mampu mengimplementasikan kebijakan-kebijakan yang telah ditetapkan pemerintah.

Entrepreneurship dalam kontek pendidikan, kepala sekolah dituntut untuk mampu memberikan kebijakan-kebijakan yang mampu mendukung tercapainya tujuan pendidikan. Sebuah kebijakan yang mampu memberikan nilai keunggulan sehingga memiliki nilai jual (prestasi) tinggi dibandingkan dengan sekolah-sekolah lain. Oleh karena itu keberanian kepala sekolah dalam membuat sebuah kebijakan serta kemampuannya dalam membaca peluang sangat menentukan keberhasilan kepala sekolah entrepreneurship. Berikut ini beberapa faktor yang dapat mempengaruhi keberhasilan kepala sekolah dalam mengembangkan entrepreneurship di lembaga pendidikan:

1. Kemampuan dalam mengidentifikasi tujuan yang akan dicapai.

2. Berani menanggung resiko.

3. Memiliki kompetensi managerial: merencanakan, mengorganisasi, mengkoordinasi, melaksanakan dan mengevaluasi.

4. Komitemen, kerja keras, cerdas, dan berorientasi pada tujuan.

5. Kreatif dan optimis dalam mengembangkan hubungan baik dengan pelanggan, tenaga kependidikan, guru, orang tua murid,

${ }^{25}$ Ibid., h.192-193 
masyarakat, dan dunia usaha yang berpengaruh terhadap kemajuan dan perkembangan usaha sekolah.

6. Kemampuan menerima tantangan dengan penuh tanggung jawab atas keberhasilan dan kegagalan.

7. Transparansi dalam hal manajemen keuangan. ${ }^{26}$

\section{G. Lembaga Pendidikan dengan Kemandirian Pembiayaan pendidikan}

Tidak diragukan lagi, keberadaaan lembaga pendidikan Islam di Indonesia yakni pesantren mampu mempertahankan eksistensinya dengan tetap mempertahankan kemandiriannya baik dari segi pembiayaan maupun sistem pendidikannya. Dalam kesempatan ini penulis akan mengkaji beberapa pesantren yang mampu tetap eksis dalam menyelenggarakan pendidikan dengan kemandirian pembiayaan namun mampu mengukir prestasi baik tingkat nasional maupun internasional.

\section{Pondok Pesantren Al-Amin}

Pondok pesantren Al-Amin beralamatkan di Desa Prala, Kecamatan Gemma Kabupaten Sumenep Provinsi Jawa Timur, adalah sebuah kawasan yang terletak di pesisir pulau Pegaraman. ${ }^{27}$

Sejarah berdirinya, pondok pesantren AL-AMIEN PRENDUAN tidak bisa dilepaskan dari sejarah perkembangan agama Islam di Prenduan itu sendiri. Karena Kiai Chotib (kakek

${ }^{26}$ Ibid., h. 194.

${ }^{27}$ Mohammad MuchlisSolichin, "Kemandirian Pesantren di Era Reformasi" Nuansa, Vol.9, No.1, Januari-Juni 2012. 
Vol. V, No. 1, April 2017

para pengasuh sekarang) yang memulai usaha pembangunan lembaga pendidikan Islam di Prenduan, juga merupakan Kiai yang mengembangkan Islam di Prenduan. Usaha Pembangunan lembaga ini sebenarnya merupakan kelanjutan dari usaha adik ipar beliau, Kiai Syarqowi yang hijrah ke Guluk-guluk setelah kurang lebih 14 tahun membina masyarakat Prenduan dalam rangka memenuhi amanat sahabatnya, Kiai Gemma yang wafat di Mekkah. ${ }^{28}$

Beberapa tahun kemudian, sekitar awal abad ke-20, Kiai Chotib mulai merintis pesantren dengan mendirikan Langgar kecil yang dikenal dengan Congkop. Kiai Chotib meninggal pada hari sabtu, tanggal 7 Jumadil Akhir 1349 / 2 Agustus 1930 beliau berpulang ke haribaan-Nya. Sementara putra-putri beliau yang berjumlah 8 orang sebagian besar telah meninggalkan Congkop untuk ikut suami atau membina umat di desa lain. Dan sebagian lagi masih belajar di berbagai pesantren besar maupun di Mekkah. Sejak itulah cahaya Congkop semakin redup karena regenerasi yang terlambat. Walaupun begitu masih ada kegaitan pengajian yang dibina oleh Nyai Ramna selama beberapa tahun kemudian.

Setelah meredup dengan kepergian kiai Chotib, kegiatan pendidikan Islam di Prenduan kembali menggeliat dengan kembalinya kiai Djauhari (putra ke tujuh kiai Chotib) dari Mekkah setelah sekian tahun mengaji dan menuntut ilmu kepada Ulamaulama Masjidil Haram dan Masjid Nabawi. Beliau membangun 
madrasah yang baru tersebut diberi nama Mathlabul Ulum atau Tempat Mencari Ilmu.

Madrasah ini terus berkembang dari waktu-waktu termasuk ketika harus berjuang melawan penjajahan Jepang dan masa-masa mempertahankan kemerdekaan pada tahun 45-an. Bahkan ketika KH. Djuhari harus mendekam di dalam tahanan Belanda selama hampir 7 bulan madrasah ini terus berjalan dengan normal dikelola oleh teman-teman dan murid-murid beliau. Hingga akhir tahun 1949 setelah peperangan kemerdekaan usai dan negeri tercinta telah kembali aman, madrasah Mathlabul Ulum pun semakin pesat berkembang. Murid-muridnya bertambah banyak, masyarakat semakin antusias sehingga dianggap perlu membuka cabang dibeberapa desa sekitar. Tercatat ada 5 madrasah cabang yang dipimpin oleh tokoh masyarakat sekitar madrasah. Selain mendirikan Mathlabul Ulum beliau juga mendirikan Tarbiyatul Banat yang dikhususkan untuk kaum wanita. Selain membina madrasah, KH. Djauhari tak lupa mempersiapkan kader-kader penerus baik dari kalangan keluarga maupun pemuda-pemuda Prenduan. Tidak kurang dari 20 orang pemuda-pemudi Prenduan yang dididik khusus oleh beliau.Hingga akhir tahun 1950-an Mathlabul Ulum dan Tarbiyatul Banat telah mencapai masa keemasannya.

Kemandirian dibidang ekonomi pondok pesantren tersebut, tidak terlepas dari peran lembaga pendidikan dalam masyarakat berbasis peran-serta masyarakat (community based participation), pondok pesantren al-Amin berusaha menggali dana dari berbagai 
Vol. V, No. 1, April 2017

sumber atau potensi yang tersedia dalam masyarakat. Penggalian sumber dana itu dapat berasal dari dalam maupun luar lingkungan pondok pesantren,

Kemandirian pembiayaan pondok pesantren al-amin tercermin dari beberapa usaha yang berhasil dikembangkan pondok pesantren. hal ini sebagaimana disebutkan dalam sebuah penelitian yang dilakukan oleh Umar Bukhori, Mohammad Muchlis Shalichin dan Achmad Muchlis menjelaskan bahwa:

Koperasi Pondok Pesantren (KOPONTREN)yang terdiri Unit wartel, dikelola oleh Kopontren dantersebar diseluruh lembaga Pondok Pesantren, 2) Toko bahan bangunan, 3). Unit Home Industri, unit ini mempunyai lima program, yaitu: peningkatan, omset usaha, pendiriantempat yang layak untuk produksi, mengkoordinir usaha dalam pondok, memperluas jangkauan pasar dan pengadaan makanan ringan yang memenuhi standar kesehatan.4). Unit Jasa Rental, untuk sementara masih memfokuskan pada rental komputer yang digunakan oleh para santri dan masyarakat luas dengan menggunakan jasa ARC (AlAmin Rental Komputer).5) Unit kesejahteraan Keluarga, bergerak dibidang ritel yang menjadi soko guru dengan memberikan pelayanan memenuhi segala kebutuhan keluarga besar penghuni dan warga sekitarnya. 6) Unit percetakan, unit ini berangkat dari kebutuhan ponok pesantren dalam bidang percetakan, namun dalam perkembangannya menjadi salah satu percetakan terkemuka di Madura. 7) Unit jasa transportasi, unit ini mengelola transportasi darat dan hanyamemiliki satu unit bus dan beberapa colt/taksi yang 
disewakan untuk umum. Pengembangan usaha pondok pesantren al-Amin yang dikelola oleh KOPONTREN ini, dikembangkan melalui modal/saham pesantren sebesar $35 \%$, sedangan $65 \%$ modal/saham berasal dari para guru. 1)Badan Usaha Non Koperasi (BUNK) pondok pesantren Pengembangan usaha non koperasi.: a)Unit pengelolaan rajungan, unit usaha ini belokasi di desa Pekandangan dan mempunyai prospek serta nilai ekonomi yang sangat strategis.b) Pabrik Es,unit usaha ini juga berpotensi untuk meningkatkan pengembangan ekonomi berbasis pesantren dalam kerangka pengembangan ekonomi umat dibawah menengah keatas. c) SPBU, unit ini juga menpunyai prospek serta nilai ekonomi yang sangat strategis dalam pemberdayaan ekonomi kerakyatan dilingkungan pondok pesantren al-Amin.d) Peternakan dan perkebunan, unit ini juga berpotensi dan bernilai strategis dalam pengembangan ekonomi masyarat bawah sekitar pesantren. e) Unit perusahaan tahu-tempe, unit ini juga berpotensi dalam mengembangan ekonomi kerakyatan. f) Perusahaan Air Minum Kemasan "Lana", unit ini juga mempunyai prospek serta nilai ekonomi yang sangat strategis bagi pengembangan pengelolaan pesantren. $^{29}$

Pondok pesantren al-Amin mengembangkan harta wakafnya, yaitu dengan metode pengembangan wakaf produktif yang diperoleh atau mendapat modal dari uang (cash waqf). ${ }^{30}$

${ }^{29}$ Mohammad MuchlisSolichin, "Kemandirian Pesantren di Era Reformasi" Nuansa, Vol.9, No.1, Januari-Juni 2012. h. 206-207.

${ }^{30}$ Ibid. 
Vol. V, No. 1, April 2017

\section{Pondok Pesantren Asyariyyah Nurul Iman Parung}

Pondok Pesantren Asyariyyah Nurul Iman yang berlokasikan di J1. Nurul Iman, Desa Bojong Sari, Kecamatan Bojong Sempo, Parung-Bogor merupakan salah satu pondok pesantren yang memiliki kemandirian dalam segi pembiayaan. Pondok pesantren Al-Ashriyyah Nurul Iman didirkan oleh As Syekh Habib Saggaf Bin Mahdi Bin Syekh Abi Bakar Bin Salim. Berdirinya pondok pesantren ini didasari oleh rasa prihatin dan sedih dengan kondisi yang dialami oleh para remaja yang putus sekolah disebabkan ketidak mampuan untuk melanjutkan pendidikan ke jenjang yang lebih tinggi disebabkan krisis moneter yang berakibat pada krisis moral dimana-mana. Kondisi inilah yang menguatkan niat untuk mendidirkan sebuah lembaga pendidikan gratis sebagai solusi bagi para remaja yang mengalami putus sekolah disebabkan ketiadaan biaya untuk melanjutkan pendidikan ke jenjang yang lebih tinggi. ${ }^{31}$

Santri yang belajar di Pondok pesantren Asyariyyah Nurul Iman berasal dari berbagai daerah mulai dari sabang sampai merauke dengan jumlah ribuan. Menariknya adalah semua santri di Al-Iman bebas biaya mulai dari tempat tinggal, makan, minum, listrik, maupun pendidikan, gratis secara penuh. Adapun Jenjang pendidikan di Pondok Pesantren Asyariyyah Nurul Iman lengkap, mulai dari PAUD, TK, SD, SMP, SMA. Perguruan Tinggi pun ada 
di Pondok Pesantren Al-Ashriyyah Nurul Iman, yaitu Sekolah Tinggi Agama Islam Nurul Iman (STAINI) Parung-Bogor. ${ }^{32}$

Keberhasilan perekonomian pondok pesantren tidak terlepas dari peranan santri dalam mewujudkan kemandirian pembiayaan di pondok pesantren. Melalui pemberdayaan santri dengan memberikan arahan, bimbingan, motivasi serta doa dari kiyai santri mampu ikut andil dalam mewujudkan perekonomian pondok pesantren.Pemberdayaan di pondok pesantren Asyariyyah Nurul Imandikhususkan bagi santri yang telah menamatkan pendidikan Strata Satu (S1) untuk melakukan pengabdian selama dua tahun. Pengabdian ini bertujuan untuk mengaplikasikan pengetahuan yang telah didapat selama belajar di Pondok pesantren. Terdapat tiga bidang pengabdian yang dapat dilakukan santri yakni: 1) bidang pendidikan, 2) Bidang kepesantrenan, dan 3) bidang kewirausahaan. ${ }^{33}$

Melalui pemberdayaan santri ini baik dibidang pendidikan, kepesantrenan dan kewirausahaan pondok pesantren mampu melahirkan santri yang ttidak hanya memiliki ilmu secara teori akan tetapi santri juga mendapatkan ilmu yang sifatnya empiris (praktek lapangan). Selain itu dengan pemberdayaan ini santri dapat memaksimalkan segala daya yang ada di pondok pesantren untuk memaksimalkan pencapaian tujuan pendidikan sekaligus

32 http://www.klikanggaran.com/komunitas/mengenal-lebih-dekat-ulamapohon-uang.html?

fb_comment_id $=1175797045818199 \_1175805499150687 \# f 1$ afeeefcaa8508

33 Prima Prayitno, Pemberdayaan Sumberdaya Santri melalui entrepreneurship, h. 319 
Vol. V, No. 1, April 2017

keuntungan baik secara finansial maupun prestasi akademik sehingga pondok pesantren dapat mandiri dalam segi pembiayaan hingga saat ini. Hal ini sebagaimana dijelaskan dalam penelitian sebagai berikut:

"Dengan beberapa bekal yang diberikan dari macam-macam unit kewirausahaan yang ada disana, diantaranya adalah meliputi; Daur Ulang Sampah, Toko Nurul Iman, Pabrik Air Hexagonal OINTIKA, Pabrik Tahu, Pabrik Roti, Nurul Iman Offset, Budidaya Ikan Air Tawar dan Ikan Hias, Pembuatan Pupuk Organik, Pertanian, Paving Block, Peternakan Sapi dan Kambing, Susu Kedelai, Even Organizer, dan konveksi Nurul Iman. Hal ini dimulai dengan usaha yang sangat sederhana yaitu daur ulang sampah. Namun dengan profesionalitas yang dijalankanlambat laun tumbuh dan berkembang secara maksimal, hingga dapat menopang kebutuhan dan semua kegiatan operasional lembaga pendidikan tersebut. Tidak hanya biaya pendidikan yang dijamin oleh lembaga tersebut, namun segala kebutuhan hidup yang diperlukan siswa pun dipenuhi.

\section{H. Penutup}

Kepemimpinan entrepreneurship kepala sekolah adalah kepemimpinan seorang kepala sekolah yang mempunyai kemampuan mengantisipasi perubahan, yang mampu menunjukkan dengan jelas visi yang ingin diwujudkan, berfikir strategis, fleksibel, yang mampu mengantisipasi perubahan, serta berorientasi pada masa depan. Kepala 
sekolah yang memiliki jiwa entrepreneurship akan senantiasa memiliki solusi dalam menghadapi perubahan.

Dari segi pembiayaan pendidikan, kepala sekolah entrepreneur akan berupaya menggali dana dari berbagai sumber, baik itu dana dari pemerintah, masyarakat, maupun usaha yang dikelola oleh sekolah sendiri. Kepala sekolah entrepreneur akan memberdayakan segala sumberdaya sekolah untuk mendapatkan keuntungan sehingga kepala sekolah entrepreneur mampu mandiri secara pembiayaan. 
Vol. V, No. 1, April 2017

\section{DAFTAR PUSTAKA}

Anonim, 2013, Al-qur'an Terjemah \& Penjelasan Ayat Tentang Wanita, Solo: Tiga Serangkai.

Ahmad Warson Munawir, 1997, Al-Munawwir, Yogyakarta: Pustaka Progressif.

Akdon et al, 2015, Manajemen Pembiayaan Pendidikan, Bandung: Rosdakarya.

Herabudin, 2009, Administrasi dan Supervisi Pendidikan, Bandung: Pustaka Setia.

Imam Musbikin, 2013, Menjadi Kepala Sekolah yang Hebat, Pekanbaru: Zanafa.

Jejen Musfah, 2015, Manajemen Pendidikan: Teori, Kebijakan, dan Praktik. Jakarta: Prenada Media Group.

Kasmir, 2014, Kewirausahaan,Jakarta: RajaGrafindo Persada.

Miftah Thoha, 2012, Kepemimpinan dalam Manajemen, Jakarta: Rajawali Pers.

Mujamil Qomar, 2008, Manajemen Pendidikan Islam: Strategi Baru Pengelolaan Lembaga Pendidikan Islam. Jakarta: Erlangga.

Mulyasa, 2015, Manajemen \& Kepemimpinan Kepala Sekolah,Jakarta: Bumi Aksara.

Muhaimin et al, 2011, Manajemen Pendidikan: Aplikasinya dalam Penyususnan Rencana Pengembangan Sekolah/ Madrasah. Jakarta: Kencana Prenada Media Group.

Mohammad Muchlis Solichin, 2012, "Kemandirian Pesantren di Era Reformasi” Nuansa, Vol.9, No.1, Januari-Juni 
Prima Prayitno, Pemberdayaan Sumberdaya Santri melalui entrepreneurship.

Sulistiyorini, 2009, Manajemen Pendidikan Islam: Konsep, strategi, dan Aplikasi, Yogyakarta: Teras.

Uhar Suharsaputra, 2016, Kepemimpinan Inovasi Pendidikan:Mengembangkan Spirit Entrepreneurship Menuju Learnig School. Bandung: Refika Aditama.

http://www.nuruliman.or.id/sejarah-pesantren

http://www.klikanggaran.com/komunitas/mengenal-lebih-dekatulama-pohonuang.html?fb_comment_id=1175797045818199_117580549 9150687\#f1afeeefcaa8508 
